\title{
Proteomic Analysis of Human Brain Microvascular Endothelial Cells Reveals Differential Protein Expression in Response to Enterovirus 71 Infection
}

\author{
Wenying Luo, ${ }^{1,2}$ Jiayu Zhong, ${ }^{1,3}$ Wei Zhao, ${ }^{1}$ Jianjun Liu, ${ }^{4}$ Renli Zhang, ${ }^{4}$ Liang Peng, \\ Wenxu Hong, ${ }^{4}$ Sheng He Huang, ${ }^{1,6}$ and Hong Cao ${ }^{1}$ \\ ${ }^{1}$ Department of Microbiology, School of Public Health and Tropical Medicine, Southern Medical University, Guangzhou 510515, China \\ ${ }^{2}$ Department of Clinical Laboratory, Affiliated Hospital of Guangdong Medical College, Zhanjiang 524001, China \\ ${ }^{3}$ Central Laboratory, Guangzhou Women and Children's Medical Center, Guangzhou 510623, China \\ ${ }^{4}$ Shenzhen Center for Disease Control and Prevention, Shenzhen 518055, China \\ ${ }^{5}$ Clinical Laboratory, The Second Affiliated Hospital of Guangzhou Medical College, Guangzhou 510260, China \\ ${ }^{6}$ Saban Research Institute, Children's Hospital Los Angeles, University of Southern California, Los Angeles, CA 90027, USA
}

Correspondence should be addressed to Hong Cao; gzhcao@smu.edu.cn

Received 13 November 2014; Accepted 16 January 2015

Academic Editor: Amogh A. Sahasrabuddhe

Copyright (C) 2015 Wenying Luo et al. This is an open access article distributed under the Creative Commons Attribution License, which permits unrestricted use, distribution, and reproduction in any medium, provided the original work is properly cited.

\begin{abstract}
2D DIGE technology was employed on proteins prepared from human brain microvascular endothelial cells (HBMEC), to study the differentially expressed proteins in cells at $0 \mathrm{~h}, 1 \mathrm{~h}, 16 \mathrm{~h}$, and $24 \mathrm{~h}$ after infection. Proteins found to be differentially expressed were identified with matrix-assisted laser desorption/ionization time-of-flight/time-of-flight mass spectrometry (MALDITOF/TOF MS) analysis. We identified 43 spots showing changes of at least 2.5 fold up- or downregulated expressions in EV71-infected cells at different time when comparing to control, and 28 proteins could be successfully identified by MALDI TOF/TOF mass spectrometry analysis. 4 proteins were significantly upregulated, and 6 proteins were downregulated, another 18 proteins were different expression at different incubation time. We identified changes in the expression of 12 cellular metabolism-related proteins, 5 molecules involved in cytoskeleton, 3 molecules involved in energy metabolism, 2 molecules involved in signal transduction, 1 molecule involved in the ubiquitin-proteasome pathway, 1 molecule involved in cell cycle, 1 molecule involved in apoptosis-related protein, 1 molecular chaperone, and 2 unknown proteins. These findings build up a comprehensive profile of the HBMEC proteome and provide a useful basis for further analysis of the pathogenic mechanism that underlies EV71 infections to induce severe neural complications.
\end{abstract}

\section{Introduction}

Human enterovirus 71 (EV71) was first described during an outbreak with central nervous system complications in 1974 [1], which is a small, nonenveloped positive- stranded RNA virus that belonging to the enterovirus genus of the Picornaviridae family [2]. EV71 is a major pathogen of hand-foot-andmouth disease (HFMD); however, there were greater numbers of fatal cases of HFMD with symptoms of central nervous system (CNS) occurred in Taiwan [3], western Australia [4], Malaysia [5], Japan [6], Singapore [7], and South Korea [8] during the last decade. Since 2008, in the mainland of China, large outbreaks of HFMD have been reported and resulted in millions of infections and hundreds of deaths in children. In China, it is reported that many cases associated aseptic meningitis complications infected by Enterovirus, most of which is EV71 pathogen [9].

Many data show that EV71 infection has a complex pathogenesis and that the central nervous system (CNS) is likely the main target of the EV71 virus [10]. The well-established murine and cynomolgus monkey models have demonstrated that EV71 infection may cause neurological lesions in the CNS [11, 12]; recently, EV71 Virus infected rhesus monkeys through four route can result in lesion in the CNS [13]. However, the mechanism that underlies EV71 infections to induce severe neural complications in patients still remains 
unknown. Therefore, it is very important to elucidate pathogenic mechanism of EV71 CNS infection.

The BBB which is primarily constituted by the brain capillary endothelial cells interacts with neighboring cells, such as pericytes, astrocytes, and neurons to maintain the barrier integrity [14-16]. The human brain microvascular endothelial cells (HBMEC) are a special type of cell that constitute the BBB [17]. Like poliovirus, EV71 transmitted by the fecal-oral route has an affinity for cells in the central nervous system (CNS) and manifests as poliomyelitis-like paralysis [18]. Proteomics analysis is currently considered to be a powerful tool for global evaluation of protein expression. In this study, proteomics analyses of HBMEC after EV71 infection were performed. First, we found EV71 could infect and replicate in HBMEC through detecting EV71 RNA [19]. Secondly, the changes progress of HBMEC proteome induced by EV71 was explored. We found EV71-infected HBMEC can induce 28 differently expressed protein spots compared with control. These proteins might affect BBB dysfunction and lead to the development of EV71 CNS disease.

\section{Material and Methods}

2.1. Materials. HBMEC was a generous gift from professor Huang, (University of Southern California, USA). Human embryonic rhabdomyosarcoma (RD) cells were kindly provided by the Centre for Disease Control and Prevention of Guangdong Province. The newly identified strain of EV71 (KC122766) was isolated from a rectal swab specimen of a 6year-old male which was diagnosed as critical care HFMD with encephalitis complications. EV71 were amplified by using RD cells. Vero cells were conserved in our laboratory. DJ-1, vimentin, and heat shock proteins 27 rabbit antihuman polyclonal antibody were obtained from Santa Cruz Biotechnology (Santa, USA). All other chemicals in this study were analytical grade.

\subsection{Preparation of Virus Stocks and Virus Titration. EV71} were amplified by using RD cells. Virus was propagated in RD cells which were maintained in DMEM supplemented with $10 \%$ heat inactivated FBS and antibiotics. Briefly, 80 90\% confluent monolayers of RD cells were inoculated with the virus; once $90 \%$ of the cells showed cytopathic effect (CPE), the culture medium and cell debris were harvested and were repeated freezing and thawing three times, cell debris was removed by centrifugation at $1,000 \mathrm{~g}$ for $10 \mathrm{~min}$. Supernatants were filtered through a $0.22 \mu \mathrm{L}$ membrane filter (Millipore, Bedford, MA) and stored at $-80^{\circ} \mathrm{C}$ before use. Furthermore, the virus titers were determined by a plaque assay using vero cells as described in [20]. Plaques developed by series dilute suspension of EV71 virus in Vero cell cultures $96 \mathrm{~h}$ postinfection after crystal violet staining. Scoring was done by counting the plaques in each well.

\subsection{Comparative Proteome Analyses of HBMEC \\ Protein Expression in Response to EV71 Infection}

2.3.1. HBMEC Infection and Protein Extraction. HBMEC were first seeded in four $75 \mathrm{~cm}^{2}$ culture flasks. Then, cells were infected with EV71 Strain (KC122766) at a MOI of 5. As a negative control, one culture flask was mock infected with DMEM. Briefly, time was set as $0 \mathrm{~h}$ when HBMEC was mock infected with DMEM. Time was set as $1 \mathrm{~h}$ after HBMEC was infected with EV71 for $1 \mathrm{~h}$. At $1 \mathrm{~h}, 16 \mathrm{~h}$, and $24 \mathrm{~h}$ after infection, infected cells and mock infected cells $(0 \mathrm{~h})$ were harvested by scraping and washed with the PBS twice $(0.01 \mathrm{M}$, $\mathrm{pH} 7.4)$ at $4^{\circ} \mathrm{C}$. Cells were then pelleted by centrifuging at $4^{\circ} \mathrm{C}$ (150 $\mathrm{g}$ for $10 \mathrm{~min}$ ), and $800 \mu \mathrm{L}$ ice-cold lysis buffer (containing $20 \mathrm{mM}$ Tris base, $2 \mathrm{M}$ Thiourea, $7 \mathrm{M}$ Urea, and 2\% Chaps) was added into the centrifuge tube for $60 \mathrm{~min}$ on ice. The protein extract supernatant was collected by centrifuging at $16,000 \mathrm{~g}$ for $1 \mathrm{~h}$ at $4^{\circ} \mathrm{C}$. The proteins were separated into several equal parts $(125 \mu \mathrm{L})$ and were further purified by precipitation with chloroform/methanol as described [21] and stored at $-80^{\circ} \mathrm{C}$ until further analysis.

2.3.2. Two-Dimensional Gel Electrophoresis. The concentrations of the extracted proteins were measured with the Infinite M1000 spectrophotometer (Tecan, Switzerland) at $480 \mathrm{~nm}$. Samples were then diluted to $1200 \mu \mathrm{g}$ with rehydration buffer (containing $2 \mathrm{M}$ Thiourea, $7 \mathrm{M}$ urea, 4\% Chaps) and applied to $24 \mathrm{~cm}$ (pH 4-7) ReadyStrip IPG Strips. The strips were first rehydrated and then focused on the Ettan IPGphor 3 IEF system (GE, USA) with the following conditions: rehydrated for $12 \mathrm{~h}$ at $20^{\circ} \mathrm{C}(30 \mathrm{~V}), 300 \mathrm{~V}$ for $30 \mathrm{~min}$ with rapid ramping, $700 \mathrm{~V}$ for $30 \mathrm{~min}$ with rapid ramping, $1,500 \mathrm{~V}$ for $1.5 \mathrm{~h}, 9,000 \mathrm{~V}$ for $3 \mathrm{~h}$ with linear ramp, and finally $9,000 \mathrm{~V}$ for $4 \mathrm{~h}$ with rapid ramping. After equilibration with equilibration buffers (containing $100 \mathrm{mM}$ DTT and $250 \mathrm{mM}$ IAA), the gel strips were applied to second-dimensional SDS-PAGE for $45 \mathrm{~min}$ at $1 \mathrm{~W} / \mathrm{gel}$, then $4.5 \mathrm{~h}$ at $11 \mathrm{~W} /$ gel. The gels were fixed for at least $2 \mathrm{~h}$ with stationary liquid (containing 40\% ethanol, 10\% glacial acetic acid, and 68\% ( $\mathrm{m} / \mathrm{v}, \mathrm{g} / \mathrm{L})$ acetic acid sodium without water) and then stained with coomassie brilliant blue G-250 (1000 mL solution containing G-2501.2 g, ammonium sulfate $100 \mathrm{~g}$, phosphoric acid $100 \mathrm{~mL}$, methanol $200 \mathrm{~mL}$ ) for $6 \mathrm{~h}$ and subsequently destained with distilled water until background staining were negligible. In addition, the fixed gels are also stained with MS compatible silver nitrate method [22]. The silver stained gels were used for analysis and coomassie blue stained gels were used for protein identification.

2.3.3. Image Acquisition and Analysis. The gels were captured at $300 \mathrm{dpi}$ with an Image Scanner (Amershan pharmacia biotech, Piscataway, NJ). The spot intensities were determined by Image Master 2D platinum 7.0 (GE). All the experiments were done in triplicates to ensure reproducibility. Statistical analysis of protein variations was carried out in 2D gels prepared from three replicates in each group. In each group, matched spots with coefficient variation less than $50 \%$ on vol. \% were included for further between group analyses. Student's $t$-test analysis on vol. \% of matched spots between groups was done to find out significant expressional changes $(P<0.05)$. Proteins determined to be differentially expressed were selected for MS identification. 
2.3.4. In-Gel Digestion and MAlDI-TOF-TOF-MS/MS. The protein spots that were significant $(\mid$ ratio $\mid>2.5, P<0.05)$ increased or decreased in samples compared with control samples were chosen for further analysis. The differential protein spots were excised from the gel and washed twice with water. The gels were then destained and washed in $25 \mathrm{mM} \mathrm{NH}_{4} \mathrm{HCO}_{3}$ and 50\% (v/v) acetonitrile. Destaining was repeated two more times. The gel was subsequently dehydrated with $50 \mu \mathrm{L}$ acetonitrile and dried with a vacuum centrifuge. Digestion was done with $12.5 \mathrm{ng} / \mu \mathrm{L}$ of sequencing grade modified trypsin in $25 \mathrm{mM}$ ammonium bicarbonate and incubated for $30 \mathrm{~min}$ at $4^{\circ} \mathrm{C}$, then $10 \mu \mathrm{L} 25 \mathrm{mM}$ ammonium bicarbonate was added into each tube at $37^{\circ} \mathrm{C}$ for $18 \mathrm{~h}$. The digested peptides were concentrated by centrifugation and were moved into another tube. The digested peptides were mixed with freshly prepared matrix solution $(1 \mathrm{mg}$ of HCCA in $0.3 \mathrm{~mL}$ of $0.1 \%$ TFA and $0.7 \mathrm{~mL}$ acetonitrile) in a $1: 1(\mathrm{v} / \mathrm{v})$ ratio and applied onto a target plate (MTP 600-384 anchor chip). All samples were analyzed using an Autoflex MALDI-TOF MS (Bruker Daltonik, Bremen, Germany). Peptide tolerance was set at $100 \mathrm{ppm}$ with fixed modification of cysteine carbamidomethyl, variable modification of methionine oxidated, and permitted missed cleavage of up to 1 . Trypsin cleavage of the protein is at the C-terminal side of $\mathrm{KR}$ unless next residue is P. Protein identification was achieved by a protein blast search using the NCBI protein database (http://blast.ncbi.nlm.nih.gov/Blast.cgi). The significance of the change in spot intensities was analyzed by $\chi 2$ test with 2 degrees of freedom $(\alpha=0.05)$.

\subsubsection{Validation of the MAlDI-TOF-TOF-MS/MS Results by} Western Blot. Western blot analysis was performed to ensure the reliability of the MAIDI-TOF-TOF-MS/MS results. Selected differentially expressed proteins in cell samples were verified as previously reported [23]. HBMEC infection, protein extraction and protein concentrations were performed as previously described in this study. Rabbit anti-DJ-1, vimentin and heat shock proteins 27 polyclonal antibodies were primary antibodies for the immunodetection. HRP-conjugated goat-anti rabbit IgG was used as secondary antibody (Santa, USA). Tubulin and GAPDH (Santa, USA) was used as a loading control. Bands were visualized by chemiluminescence with ChemiDocXRC+ Imaging System (Bio-Rad, USA) using ECL detection reagents (GE Healthcare, USA). Quantification of the detected bands density value was performed using the version 4.6.2 Quantity One software (Bio-Rad, USA). All immunoblots were run at least in triplicate.

2.4. Statistical Analysis. All data in this study were presented as mean \pm SD. All these statistical analyses were carried out using origin 7.5 or SPSS 13.0 for windows. Differences with $P<0.05$ were considered to be statistically significant.

\section{Results and Discussion}

The proteins of HBMEC infected by EV71 extracts were prepared and explored the 2-DE analysis. Analysis of 2D images from protein lysates of EV71-infected and mockinfected HBMEC identified 1435 matching protein spots.
There were 43 spots showing changes of at least 2.5 fold upor downregulated expressions in EV71-infected samples at different time when comparing to control (Figure 1). Among the proteins with significant expression changes, 28 proteins could be successfully identified by MALDI TOF/TOF mass spectrometry analysis (Table 1) and 15 proteins could not be successfully identified. The reason that $15 / 43$ spots were not identified might be that (1) the proteins might have characteristics of low abundance and (2) the differential protein spots might contain a variety of proteins. Of these 28 differentially expressed protein spots, 4 proteins were significantly upregulated, and 6 proteins were downregulated, and another 18 proteins were different expression at different incubation time. The four upregulated proteins were identified as protein expression at $1 \mathrm{hpi}, 16 \mathrm{hpi}$, and $24 \mathrm{hpi}$ upregulated after EV71 infection, which included splicing factor arginine/serinerich 2, ubiquinol-cytochrome c reductase core I protein, glutathione synthetase, and actin cytoplasmic 1 . The six downregulated proteins were identified as protein expression at $1 \mathrm{hpi}, 16 \mathrm{hpi}$, and $24 \mathrm{hpi}$ downregulated after EV71 infection, which included L-lactate dehydrogenase B chain OS, protein DJ-1, serine/threonine-protein phosphatase 6 catalytic subunit isoform $b$, spermidine synthase, Vimentin, and thymosin beta-10.

According to cellular functions and processes, we identified changes in the expression of 12 cellular metabolismrelated proteins (metabolic enzymes), 5 molecules involved in cytoskeleton, 3 molecules involved in energy metabolism, 2 molecules involved in signal transduction, 1 molecule involved in the ubiquitin-proteasome pathway, 1 molecule involved in cell cycle, 1 molecule involved in apoptosis-related proterin, 1 molecular chaperone, and 2 unknown proteins (Figure 2). Our studies showed that the expression of several enzyme molecules including deoxyuridine $5^{\prime}$-triphosphate nucleotidohydrolase, acyl- CoA-binding protein isoform 1 , L-lactate dehydrogenase $\mathrm{B}$ chain OS, ubiquitin-conjugating enzyme $\mathrm{E}_{2} \mathrm{~N}$, uroporphyrinogen decarboxylase, ubiquinolcytochrome $\mathrm{c}$ reductase core I protein, glutathione synthetase, and Inosine triphosphate pyrophosphatase were differentially regulated by EV71.

Heat shock proteins are the products of several distinct gene families that are required for cell survival during stress and are named according to the approximate relative molecular mass of their encoded proteins such as HSP27; heat shock proteins belong to molecular chaperones and which are reported to be crucial for virus propagation. HSP27 (spots 2) were observed to be downregulated at $1 \mathrm{hpi}$ and $16 \mathrm{hpi}$, but upregulated at $24 \mathrm{hpi}$ in the host cells infected with EV71. In order to correlate the protein expression level, we examine HSP27 protein by western blot analysis (Figure 3), from picture we can find that protein expression is downregulated at $1 \mathrm{hpi}$ and $8 \mathrm{hpi}$ compare with control, but is upregulated at $16 \mathrm{hpi}$ and $24 \mathrm{hpi} \mathrm{compare} 1 \mathrm{hpi}$.

Protein DJ-1, also called PARK7 protein, is encoded by the dj-1 gene, which was described to be involved in the antioxidant response of the cells and is a redox-responsive cytoprotective protein with diverse functions. DJ-1 protein was observed to be downregulated at 1 to $24 \mathrm{hpi}$. This may be due to redox potential of cells infected with EV71 is decreased; 

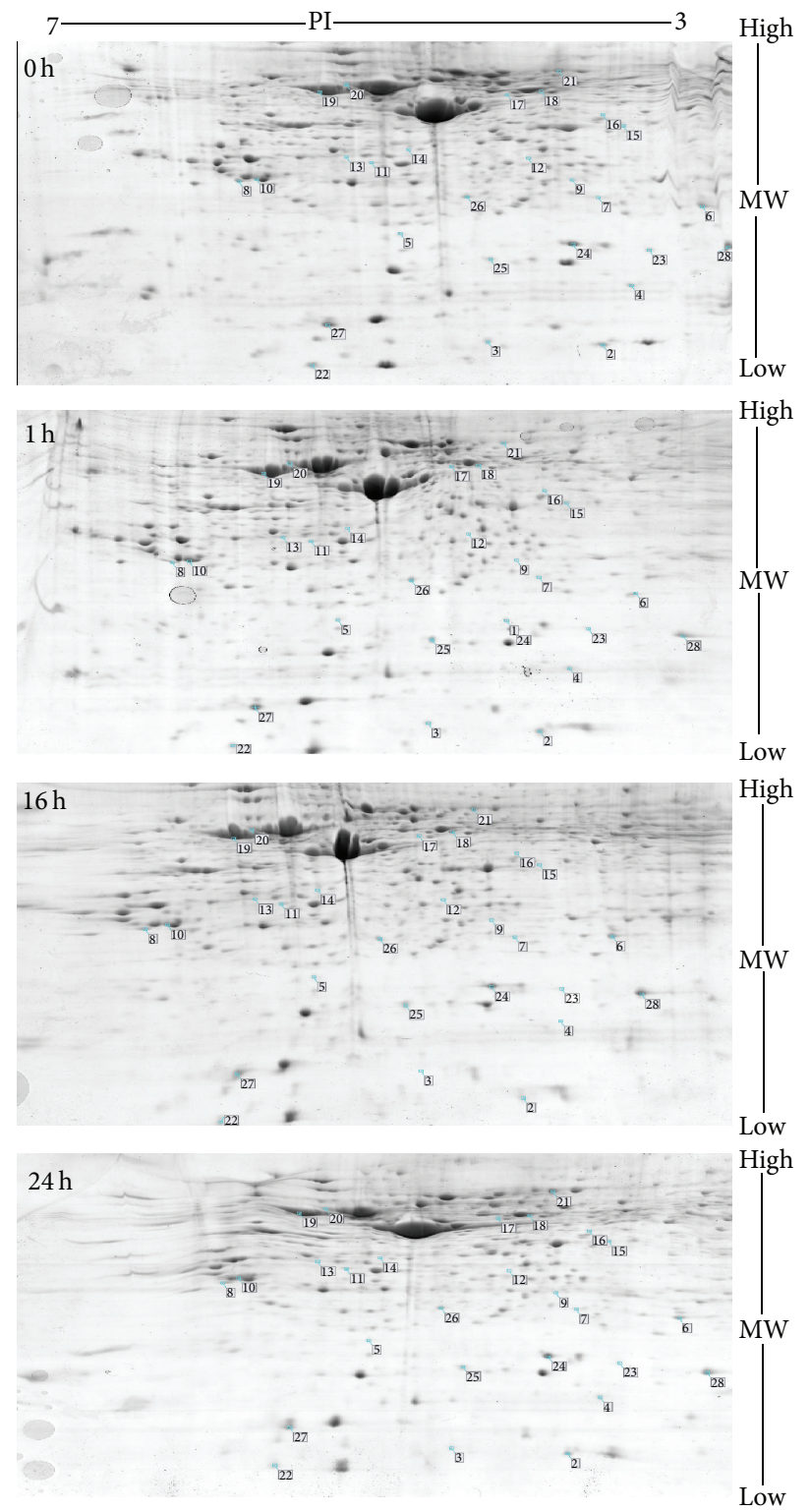

FIGURE 1: Analysis of HBMEC infected with EV71 as revealed by 2D DIGE analysis.

thus, the protein expression is decreased compared with control. We analyzed the DJ-1 protein by western blot analysis and found the protein is downregulated from 1 to $24 \mathrm{hpr}$ (Figure 4).

Stathmin-1 was observed to be upregulated at $1 \mathrm{hpi}$ and $16 \mathrm{hpi}$, but downregulated at $24 \mathrm{hpi}$ in the host cells infected with EV71, Stathmin-1 is involved in the regulation of the microtubule filament system by destabilizing and preventing assembly of microtubules, Thus, its increased expression may be associated with destroying the cell in the early stage of EV71 infection. But the downregulation of Stathmin-1 at 24 hpi supported the previous findings by Leong and Chow when RD cells were infected with EV71 MS/7423/87 strain, which is expected to induce growth arrest in EV71-infected cells [24]. Deoxyuridine triphosphate nucleotidohydrolase
(dUTPase) was responsible for maintaining low intracellular levels of dUTP, thus preventing the incorporation of dUTP into DNA $[25,26]$. It widely exists in eukaryotic and prokaryotic cells, viruses, and other biological organisms [27]. Study demonstrated expression or the activity of dUTPase is related to EBV replication [28]. In this study, dUTPase only appeared at $1 \mathrm{hpi}$ but was not detected at $0 \mathrm{~h}, 16 \mathrm{hpi}$, and $24 \mathrm{hpi}$. This showed that dUTPase might be related to the process of EV71 attaching and penetrating into HBMEC. But, its mechanism remains to be further studied. Acyl-CoA-binding protein (ACBP), a low molecular mass (m) $(\sim 10 \mathrm{kDa})$ soluble protein ubiquitous in eukaryotes, plays an important housekeeping role in lipid metabolism by maintaining the intracellular acyl-CoA pool. ACBP is involved in lipid biosynthesis and transport, gene expression, and membrane biogenesis [29]. In 
TABLE 1: Differential proteins identified by mass spectrometry (MS) after 2D DIGE of in HBMEC from EV71-infected contrast to mockinfected.

\begin{tabular}{|c|c|c|c|c|c|c|c|c|}
\hline \multirow{2}{*}{$\begin{array}{l}\text { Spot } \\
\text { number }\end{array}$} & \multirow{2}{*}{ Protein Name } & \multirow{2}{*}{ Gene name } & \multirow{2}{*}{ Accession number } & \multirow{2}{*}{$\begin{array}{c}\text { Nominal mass } \\
\text { (Mr)/calculated PI }\end{array}$} & \multicolumn{3}{|c|}{ Infection time (hpi) } & \multirow{2}{*}{$\begin{array}{c}\text { Sequence } \\
\text { coverage (\%) }\end{array}$} \\
\hline & & & & & 1 & 16 & 24 & \\
\hline 1 & $\begin{array}{c}\text { Deoxyuridine } \\
5^{\prime} \text {-triphosphate } \\
\text { nucleotidohydrolase }\end{array}$ & DUT & gi|3041664 & $26975 / 9.65$ & - & 0 & 0 & 11 \\
\hline 2 & & ACBP1 & gi|10140853 & $11786 / 5.41$ & $\uparrow$ & $\downarrow$ & $\downarrow$ & 34 \\
\hline 3 & $\begin{array}{c}\text { L-lactate } \\
\text { dehydrogenase B } \\
\text { chain OS }\end{array}$ & LDHB & gi|291575128 & $36900 / 5.71$ & $\downarrow$ & $\downarrow$ & $\downarrow$ & 8 \\
\hline 4 & $\begin{array}{l}\text { Ubiquitin- } \\
\text { conjugating enzyme } \\
\text { E2 N }\end{array}$ & UBE2N & gi| 4507793 & $17184 / 6.13$ & $\uparrow$ & $\downarrow$ & $\uparrow$ & 19 \\
\hline 5 & $\begin{array}{l}\text { Unnamed protein } \\
\text { product }\end{array}$ & $\begin{array}{l}\text { Unnamed gene } \\
\text { product }\end{array}$ & gi|194375299 & $40819 / 5.78$ & $\uparrow$ & $\uparrow$ & $\uparrow$ & 23 \\
\hline 6 & Protein DJ-1 & DJ-1, PARK7 & gi|31543380 & $20050 / 6.33$ & $\downarrow$ & $\downarrow$ & $\downarrow$ & 20 \\
\hline 7 & $\begin{array}{l}\text { Microtubule- } \\
\text { associated protein } \\
\text { RP/EB family } \\
\text { member } 1\end{array}$ & MAPRE1 & gi|6912494 & $30151 / 5.02$ & $\downarrow$ & $\downarrow$ & $\uparrow$ & 20 \\
\hline 8 & $\begin{array}{l}\text { Proteasome subunit } \\
\text { alpha type- } 5\end{array}$ & PSMB5 & gi|7106387 & $26579 / 4.74$ & $\downarrow$ & $\uparrow$ & $\downarrow$ & 43 \\
\hline 9 & Heat shock protein 27 & HSP27 & gi|662841 & $22427 / 7.83$ & $\downarrow$ & $\downarrow$ & $\uparrow$ & 13 \\
\hline 10 & $\begin{array}{l}\text { 14-3-3 protein } \\
\text { beta/alpha }\end{array}$ & YWHAB & gi|197692221 & $28209 / 4.76$ & $\uparrow$ & $\downarrow$ & $\uparrow$ & 28 \\
\hline 11 & $\begin{array}{c}\text { Nuclear chloride } \\
\text { channel }\end{array}$ & CLIC & gi| 4588526 & $27249 / 5.02$ & $\uparrow$ & $\downarrow$ & $\uparrow$ & 16 \\
\hline 12 & $\begin{array}{l}\text { Serine/threonine- } \\
\text { protein phosphatase } 6 \\
\text { catalytic subunit } \\
\text { isoform b }\end{array}$ & PPP6B & gi|4506029 & $35806 / 5.43$ & $\downarrow$ & $\downarrow$ & $\downarrow$ & 28 \\
\hline 13 & $\begin{array}{c}\text { Splicing factor, } \\
\text { arginine/serine-rich } 2\end{array}$ & SCAF1 & gi|62898065 & $25487 / 5.12$ & $\uparrow$ & $\uparrow$ & $\uparrow$ & 15 \\
\hline 14 & Spermidine synthase & SRM & gi|531202 & $34360 / 5.21$ & $\downarrow$ & $\downarrow$ & $\downarrow$ & 5 \\
\hline 15 & $\begin{array}{l}\text { Serine/threonine- } \\
\text { protein phosphatase } \\
\text { PP1-beta catalytic } \\
\text { subunit isoform } 1\end{array}$ & PPP1CB & gi|4506005 & $37961 / 5.84$ & $\uparrow$ & $\downarrow$ & $\downarrow$ & 25 \\
\hline 16 & $\begin{array}{l}\text { Uroporphyrinogen } \\
\text { decarboxylase }\end{array}$ & UROD & gi|1322019 & $41119 / 5.77$ & $\uparrow$ & $\downarrow$ & $\uparrow$ & 20 \\
\hline 17 & $\begin{array}{l}\text { Ubiquinol- } \\
\text { cytochrome c } \\
\text { reductase core I } \\
\text { protein }\end{array}$ & UQCRC1 & gi|515634 & $53270 / 5.94$ & $\uparrow$ & $\uparrow$ & $\uparrow$ & 15 \\
\hline 18 & $\begin{array}{l}\text { Glutathione } \\
\text { synthetase }\end{array}$ & GSS & gi|4504169 & $52523 / 5.67$ & $\uparrow$ & $\uparrow$ & $\uparrow$ & 24 \\
\hline 19 & Vimentin & VIM & gi|62414289 & $53676 / 5.06$ & $\downarrow$ & $\downarrow$ & $\downarrow$ & 7 \\
\hline 20 & Actin, cytoplasmic 1 & ACTB & gi|4501885 & $42052 / 5.29$ & $\uparrow$ & $\uparrow$ & $\uparrow$ & 29 \\
\hline 21 & Serum albumin & PRO2044 & gi|6650826 & $30084 / 7.70$ & $\downarrow$ & $\uparrow$ & $\uparrow$ & 5 \\
\hline 22 & Thymosin beta-10 & TMSB10 & gi|339697 & $5701 / 6.45$ & $\downarrow$ & $\downarrow$ & $\downarrow$ & 16 \\
\hline 23 & $\begin{array}{l}\text { Transcription factor } \\
\text { BTF3 homolog } 4\end{array}$ & BTF3L4 & gi|29789195 & $17260 / 5.95$ & $\downarrow$ & $\downarrow$ & $\uparrow$ & 5 \\
\hline 24 & Superoxide dismutase & SOD1 & gi|4507149 & $16154 / 5.70$ & $\downarrow$ & $\downarrow$ & $\uparrow$ & 59 \\
\hline 25 & Stathmin isoform a & STMN1 & gi|5031851 & $17292 / 5.76$ & $\uparrow$ & $\uparrow$ & $\downarrow$ & 15 \\
\hline 26 & $\begin{array}{c}\text { Inosine triphosphate } \\
\text { pyrophosphatase }\end{array}$ & ITPA & gi|13398328 & $21827 / 5.78$ & $\downarrow$ & $\downarrow$ & $\uparrow$ & 18 \\
\hline
\end{tabular}


TABle 1: Continued.

\begin{tabular}{|c|c|c|c|c|c|c|c|c|}
\hline \multirow{2}{*}{$\begin{array}{l}\text { Spot } \\
\text { number }\end{array}$} & \multirow{2}{*}{ Protein Name } & \multirow{2}{*}{ Gene name } & \multirow{2}{*}{ Accession number } & \multirow{2}{*}{$\begin{array}{c}\text { Nominal mass } \\
(\mathrm{Mr}) / \text { calculated PI }\end{array}$} & \multicolumn{3}{|c|}{ Infection time (hpi) } & \multirow{2}{*}{$\begin{array}{c}\text { Sequence } \\
\text { coverage (\%) }\end{array}$} \\
\hline & & & & & 1 & 16 & 24 & \\
\hline 27 & Thioredoxin 1 & TXN1 & gi|9280551 & $11971 / 4.69$ & $\uparrow$ & $\downarrow$ & $\uparrow$ & 49 \\
\hline 28 & Cofilin-1 & CFL1 & gi|5031635 & $18719 / 8.22$ & $\downarrow$ & $\uparrow$ & $\uparrow$ & 51 \\
\hline
\end{tabular}
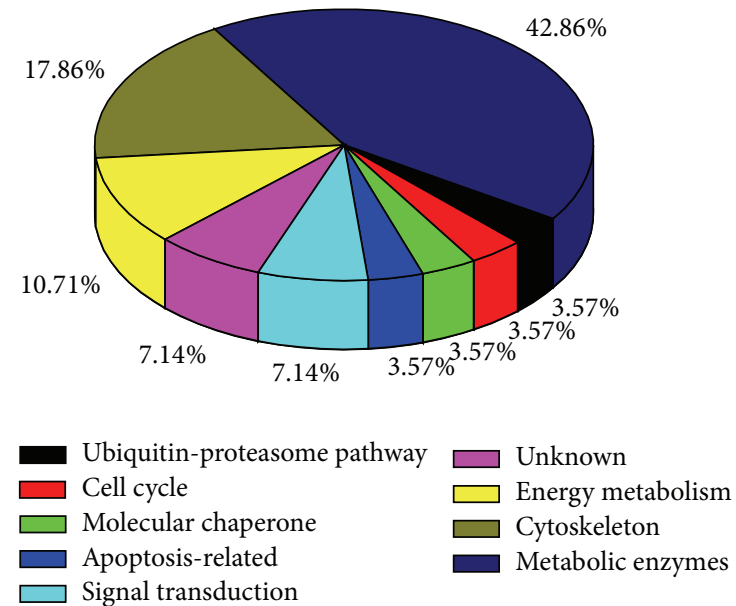

FIGURE 2: Classification analysis of 28 differentially expressed proteins found in EV71-infected HBMEC. Categorization was based on information that was obtained from the online PANTHER classification system.

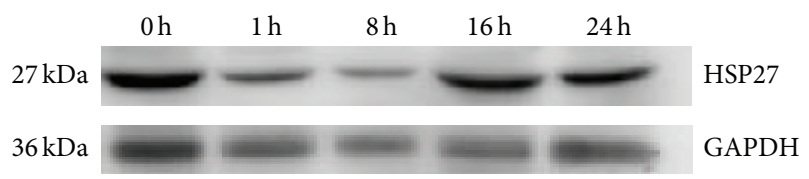

FIgURE 3: The expression of HSP27 in EV71-infected HBMEC by western blotting $(0 \mathrm{~h}$, Control; $1 \mathrm{~h}, 8 \mathrm{~h}, 16 \mathrm{~h}$, and $24 \mathrm{~h}$ represented the time of EV71 infected HBMEC).

this study, ACBP was upregulated at $1 \mathrm{hpi}$ and downregulated at 16 hpi and 24 hpi. Maybe the ACBP interact with EV71 and thus may facilitate EV71 entry.

Our current study also demonstrated that several cytoskeleton proteins including vimentin, actin, cofilin-1, and thymosin beta- 10 were differentially regulated. Actin was observed to be upregulated at 1 to $24 \mathrm{hpi}$. Studies demonstrate some viruses interact directly with the cytoskeletal transport machinery for intracellular transport. Study demonstrates cofilin-1 plays a central role in maintaining actin cytoskeletal dynamics by severing F-actin and allowing for reorganization and formation of new filaments [30-32]. The protein was also reported to be related to apoptotic cell death, cancer invasion, metastasis, and chemoresistance [33-36]. In this study, cofilin-1 was found to be downregulated at $1 \mathrm{hpi}$ and upregulated at $8 \mathrm{hpi}$ and $24 \mathrm{hpi}$. The upregulation of cofilin-1 in HBMEC at $24 \mathrm{hpi}$ is accord with the previous findings on RD cells infected with EV71 MS/7423/87 strain [24]. We also demonstrated EV71 could lead to the apoptotic

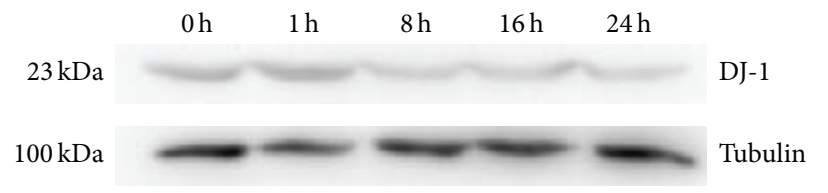

FIgure 4: The expression of DJ-1 in EV71-infected HBMEC by western blotting ( $0 \mathrm{~h}$, Control; $1 \mathrm{~h}, 8 \mathrm{~h}, 16 \mathrm{~h}$, and $24 \mathrm{~h}$ represented the time of EV71 infected HBMEC).

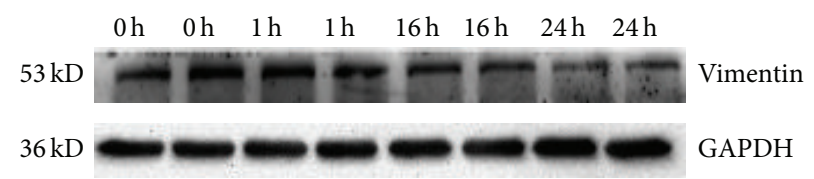

FIGURE 5: The expression of Vimentin in EV71-infected HBMEC by western blotting $(0 \mathrm{~h}$, Control; $1 \mathrm{~h}, 16 \mathrm{~h}$, and $24 \mathrm{~h}$ respresented the time of EV71 infected HBMEC).

of HBMEC [37]. Therefore, we speculated the different expression of cofilin-1 in EV71-infected HBMEC might be involved in apoptotic cell death caused by EV71 infection: further studies focusing on the functional properties of cofilin-1 and predictive value for EV71 infection may permit identification of biomarkers for EV71 infection and development of new therapeutic methods. Vimentin is the major IF protein in mesenchymal cells, which mainly assigned functions in maintaining the structural and mechanical integrity of cells and also participates in a number of critical cellular processes such as adhesion, migration and cell signalling. Vimentin was observed to be downregulated at 1 to $24 \mathrm{hpi}$. This may be due to decreased expression of vimentin is associated with inhibiting the proliferation of HBMEC. Vimentin is mainly located in the cytoplasm, but cell surface-expressed vimentin has been reported as EV71 receptor in human astrocyte cell [38]. It was also found that vimentin expression was downregulated by western analysis at $1 \mathrm{hpi}, 16 \mathrm{hpi}$, and $24 \mathrm{hpi}$. Vimentin and other cytoskeletal filaments have been shown to play important roles in virus entry and/or infection for many viruses, such as human immunodeficiency virus type 1, Japanese encephalitis virus, vaccinia virus, adenovirus type 2 , herpes simplex virus type 1, hepatitis C virus [39-41]. The studies present here are the basis to understand the interaction between viruses and the cell cytoskeleton; however, further specific experiments will define the exact mechanism of cytoskeleton in EV71-infected HBMEC (Figure 5).

EV71 infection cause central nervous system (CNS) complications whether through BBB is unclear. Furthermore, EV71 invasion will modify the patterns of protein expression 
in HBMEC, which may affect the normal physiological function of HBMEC and determine its pathogenic progress and consequence. Therefore, studies on viral infections proteomics contributes to uncover the mechanism of interaction between EV71 and HBMEC and viral molecular pathogenesis, find early biomarker of EV71 infection, develop earlier diagnostic method, evaluate therapeutic effect and prognosis and so on. In this study, we identified 28 differentially expressed protein in HBMEC after EV71 infection, and western analysis three proteins. Those differential protein expression in EV71-infected HBMEC in vitro may not completely be according to the protein level in vivo. We regretted that most of the confirmed differential protein didnot be futher tested the expression level by western blotting, but our identified three proteins have be confirmed expression level by western blotting, which have important roles in virus infection; for example, HSP27 and vimentin are associated with virus entry and/or infection, and DJ-1 protein may associated with EV71 infection caused encephalitis. Our study on HBMEC proteome of BBB in CNS may contribute to understand the severity of EV71 brain encephalitis in clinic, and some differential proteins may provide a new way to find early biomarker candidate during EV71 infection developed severe case; our work on differential protein expression of HBMEC may provide a possible insight into central nervous system complications caused by EV71 virus infection, and find new drug candidate against EV71. This study builds up a comprehensive profile of the HBMEC proteome and provides a useful basis for further analysis of the pathogenic mechanism that underlies EV71 infections to induce severe neural complications.

\section{Conflict of Interests}

The authors declare that there is no conflict of interests regarding the publication of this paper.

\section{Authors' Contribution}

Wenying Luo, Jiayu Zhong, and Wei Zhao contributed equally to this work.

\section{Acknowledgments}

This study was partially supported by the National Natural Science Foundation of China (no. 81301478 to W. Y. Luo), the Grant from School of Public Health and Tropical Medicine of Southern Medical University, China (no. GW201201), and Guangdong Medical College doctoral start task (XB1325 to W. Y. Luo).

\section{References}

[1] N. J. Schmidt, E. H. Lennette, and H. H. Ho, "An apparently new enterovirus isolated from patients with disease of the central nervous system," The Journal of Infectious Diseases, vol. 129, no. 3, pp. 304-309, 1974.
[2] M. Ho, "Enterovirus 71: the virus, its infections and outbreaks," Journal of Microbiology, Immunology and Infection, vol. 33, no. 4, pp. 205-216, 2000.

[3] M. Ho, E.-R. Chen, K.-H. Hsu et al., "An epidemic of enterovirus 71 infection in Taiwan. Taiwan Enterovirus Epidemic Working Group," The New England Journal of Medicine, vol. 341, no. 13, pp. 929-935, 1999.

[4] P. McMinn, K. Lindsay, D. Perera, and M. J. Cardosa, "Phylogenetic analysis of enterovirus 71 strains isolated during linked epidemics in Malaysia, Singapore, and Western Australia," Journal of Virology, vol. 75, no. 16, pp. 7732-7738, 2001.

[5] S. Abubakar, H.-Y. Chee, M. F. Al-Kobaisi, J. Xiaoshan, K. Bing Chua, and S. Kit Lam, "Identification of enterovirus 71 isolates from an outbreak of hand, foot and mouth disease (HFMD) with fatal cases of encephalomyelitis in Malaysia," Virus Research, vol. 61, no. 1, pp. 1-9, 1999.

[6] T. Fujimoto, M. Chikahira, S. Yoshida et al., "Outbreak of central nervous system disease associated with hand, foot, and mouth disease in Japan during the summer of 2000: detection and molecular epidemiology of enterovirus 71," Microbiology and Immunology, vol. 46, no. 9, pp. 621-627, 2002.

[7] S. Singh, C. L. Poh, and V. T. K. Chow, "Complete sequence analyses of enterovirus 71 strains from fatal and non-fatal cases of the hand, foot and mouth disease outbreak in Singapore (2000)," Microbiology and Immunology, vol. 46, no. 11, pp. 801808, 2002.

[8] Y. M. Jee, D.-S. Cheon, K. Kim et al., "Genetic analysis of the VP1 region of human enterovirus 71 strains isolated in Korea during 2000," Archives of Virology, vol. 148, no. 9, pp. 1735-1746, 2003.

[9] Z. Tao, H. Wang, Y. Li et al., "Molecular epidemiology of human enterovirus associated with aseptic meningitis in Shandong Province, China, 2006-2012," PLoS ONE, vol. 9, no. 2, Article ID e89766, 2014.

[10] T.-Y. Lin, S.-H. Hsia, Y.-C. Huang, C.-T. Wu, and L.-Y. Chang, "Proinflammatory cytokine reactions in enterovirus 71 infections of the central nervous system," Clinical Infectious Diseases, vol. 36, no. 3, pp. 269-274, 2003.

[11] Y. C. Chen, C. K. Yu, Y. F. Wang, C. C. Liu, I. J. Su, and H. Y. Lei, "A murine oral enterovirus 71 infection model with central nervous system involvement," Journal of General Virology, vol. 85, part 1, pp. 69-77, 2004.

[12] S.-M. Wang and C.-C. Liu, "Enterovirus 71: epidemiology, pathogenesis and management," Expert Review of Anti-Infective Therapy, vol. 7, no. 6, pp. 735-742, 2009.

[13] Y. Zhang, W. Cui, L. Liu et al., "Pathogenesis study of enterovirus 71 infection in rhesus monkeys," Laboratory Investigation, vol. 91, no. 9, pp. 1337-1350, 2011.

[14] E. A. Neuwelt, N. J. Abbott, L. Drewes et al., "Cerebrovascular biology and the various neural barriers: challenges and future directions," Neurosurgery, vol. 44, no. 3, pp. 604-609, 1999.

[15] J. Correale and A. Villa, "Cellular elements of the blood-brain barrier," Neurochemical Research, vol. 34, no. 12, pp. 2067-2077, 2009.

[16] N. Weiss, F. Miller, S. Cazaubon, and P.-O. Couraud, "The blood-brain barrier in brain homeostasis and neurological diseases," Biochimica et Biophysica Acta-Biomembranes, vol. 1788, no. 4, pp. 842-857, 2009.

[17] L. L. Rubin and J. M. Staddon, "The cell biology of the bloodbrain barrier," Annual Review of Neuroscience, vol. 22, pp. 11-28, 1999. 
[18] C.-M. Kung, C.-C. King, C.-N. Lee, L.-M. Huang, P.-I. Lee, and C.-L. Kao, "Differences in replication capacity between enterovirus 71 isolates obtained from patients with encephalitis and those obtained from patients with herpangina in Taiwan," Journal of Medical Virology, vol. 79, no. 1, pp. 60-68, 2007.

[19] W.-Y. Luo, W. Zhao, L. Peng et al., "Enterovirus 71 infecting human brain microvascular endothelial cells: a preliminary study," Academic Journal of Second Military Medical University, vol. 35, no. 3, pp. 240-245, 2014.

[20] S.-C. Huang, C.-L. Chang, P.-S. Wang, Y. Tsai, and H.-S. Liu, "Enterovirus 71-induced autophagy detected in vitro and in vivo promotes viral replication," Journal of Medical Virology, vol. 81, no. 7, pp. 1241-1252, 2009.

[21] D. Wessel and U. I. Flugge, "A method for the quantitative recovery of protein in dilute solution in the presence of detergents and lipids," Analytical Biochemistry, vol. 138, no. 1, pp. 141-143, 1984.

[22] L.-T. Jin, S.-Y. Hwang, G.-S. Yoo, and J.-K. Choi, "A mass spectrometry compatible silver staining method for protein incorporating a new silver sensitizer in sodium dodecyl sulfatepolyacrylamide electrophoresis gels," Proteomics, vol. 6, no. 8, pp. 2334-2337, 2006.

[23] S. S. Daoud, P. J. Munson, W. Reinhold et al., "Impact of p53 knockout and topotecan treatment on gene expression profiles in human colon carcinoma cells: a pharmacogenomic study," Cancer Research, vol. 63, no. 11, pp. 2782-2793, 2003.

[24] W. F. Leong and V. T. Chow, "Transcriptomic and proteomic analyses of rhabdomyosarcoma cells reveal differential cellular gene expression in response to enterovirus 71 infection," Cellular Microbiology, vol. 8, no. 4, pp. 565-580, 2006.

[25] A. W. Studebaker, W. P. Lafuse, R. Kloesel, and M. V. Williams, "Modulation of human dUTPase using small interfering RNA," Biochemical and Biophysical Research Communications, vol. 327, no. 1, pp. 306-310, 2005.

[26] M. V. Williams, J. Holliday, and R. Glaser, "Induction of a deoxyuridine triphosphate nucleotidohydrolase activity in Epstein-Barr virus-infected cells," Virology, vol. 142, no. 2, pp. 326-333, 1985.

[27] D. J. McGeoch, "Protein sequence comparisons show that the 'pseudoproteases' encoded by poxviruses and certain retroviruses belong to the deoxyuridine triphosphatase family," Nucleic Acids Research, vol. 18, no. 14, pp. 4105-4110, 1990.

[28] E. Kremmer, P. Sommer, and F. A. Grässer, "Epstein-Barr virus-encoded deoxyuridine triphosphate nucleotidohydrolase (dUTPase): a potential target for drug therapy," Transplantation Proceedings, vol. 29, no. 1-2, pp. 812-814, 1997.

[29] O. P. Yurchenko and R. J. Weselake, "Involvement of low molecular mass soluble acyl-CoA-binding protein in seed oil biosynthesis," New Biotechnology, vol. 28, no. 2, pp. 97-109, 2011.

[30] O. Bernard, "Lim kinases, regulators of actin dynamics," International Journal of Biochemistry and Cell Biology, vol. 39, no. 6, pp. 1071-1076, 2007.

[31] B. W. Bernstein and J. R. Bamburg, "ADF/cofilin: a functional node in cell biology," Trends in Cell Biology, vol. 20, no. 4, pp. 187-195, 2010.

[32] M. van Troys, L. Huyck, S. Leyman, S. Dhaese, J. Vandekerkhove, and C. Ampe, "Ins and outs of ADF/cofilin activity and regulation," European Journal of Cell Biology, vol. 87, no. 8-9, pp. 649-667, 2008.
[33] B. Zhu, K. Fukada, H. Zhu, and N. Kyprianou, "Prohibitin and cofilin are intracellular effectors of transforming growth factor $\beta$ signaling in human prostate cancer cells," Cancer Research, vol. 66, no. 17, pp. 8640-8647, 2006.

[34] W. Wang, S. Goswami, K. Lapidus et al., "Identification and testing of a gene expression signature of invasive carcinoma cells within primary mammary tumors," Cancer Research, vol. 64, no. 23, pp. 8585-8594, 2004.

[35] W. Wang, G. Mouneimne, M. Sidani et al., "The activity status of cofilin is directly related to invasion, intravasation, and metastasis of mammary tumors," Journal of Cell Biology, vol. 173, no. 3, pp. 395-404, 2006.

[36] B. T. Chua, C. Volbracht, K. O. Tan, R. Li, V. C. Yu, and P. $\mathrm{Li}$, "Mitochondrial translocation of cofilin is an early step in apoptosis induction," Nature Cell Biology, vol. 5, no. 12, pp.10831089, 2003.

[37] W. Y. Luo, X. J. Wu, L. Peng et al., "Enterovirus 71 induces apoptosis in human brain microvascular endothelial cells," Journal of Third Military Medical University, vol. 36, no. 13, pp. 1359-1364, 2014.

[38] N. Du, H. Cong, H. Tian et al., "Cell surface vimentin is an attachment receptor for enterovirus 71," Journal of Virology, vol. 88, no. 10, pp. 5816-5833, 2014.

[39] R. J. Mayer, J. Lowe, G. Lennox, M. Landon, K. MacLennan, and F. J. Doherty, "Intermediate filament-ubiquitin diseases: implications for cell sanitization," Biochemical Society Symposia, vol. 55, pp. 193-201, 1989.

[40] Y. Nitahara-Kasahara, M. Fukasawa, F. Shinkai-Ouchi et al., "Cellular vimentin content regulates the protein level of hepatitis $\mathrm{C}$ virus core protein and the hepatitis $\mathrm{C}$ virus production in cultured cells," Virology, vol. 383, no. 2, pp. 319-327, 2009.

[41] S. Das, V. Ravi, and A. Desai, "Japanese encephalitis virus interacts with vimentin to facilitate its entry into porcine kidney cell line," Virus Research, vol. 160, no. 1-2, pp. 404-408, 2011. 

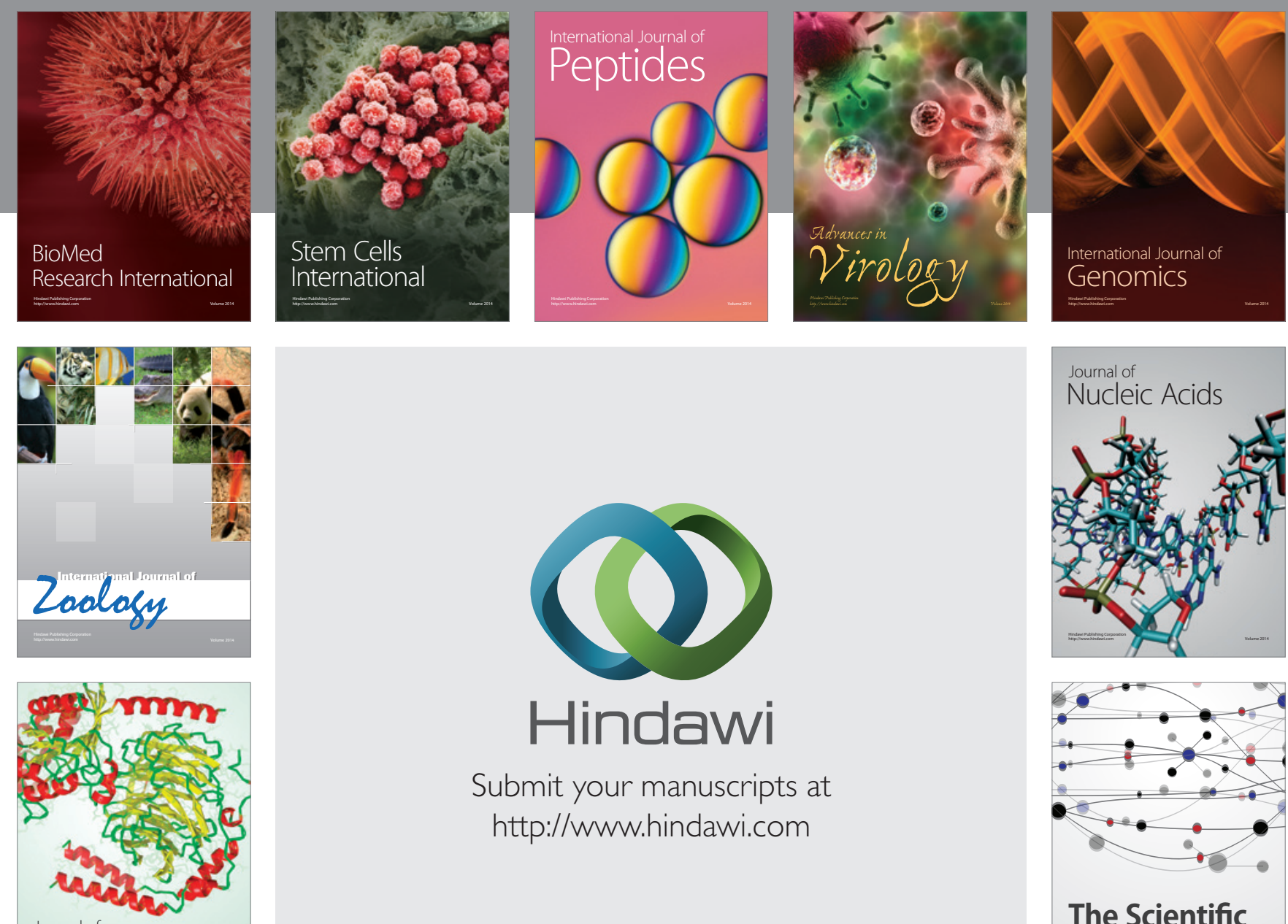

Submit your manuscripts at

http://www.hindawi.com

Journal of
Signal Transduction
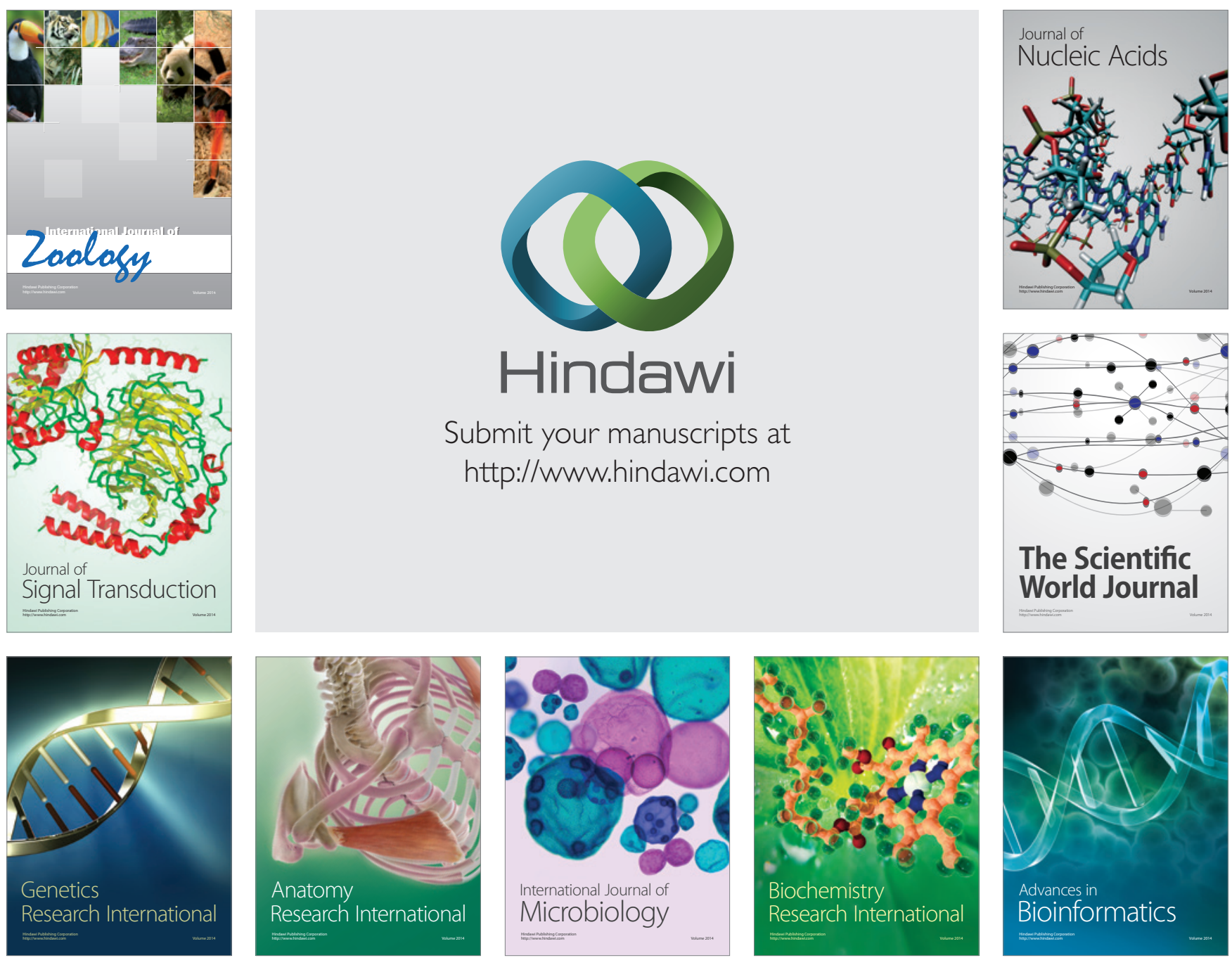

The Scientific World Journal
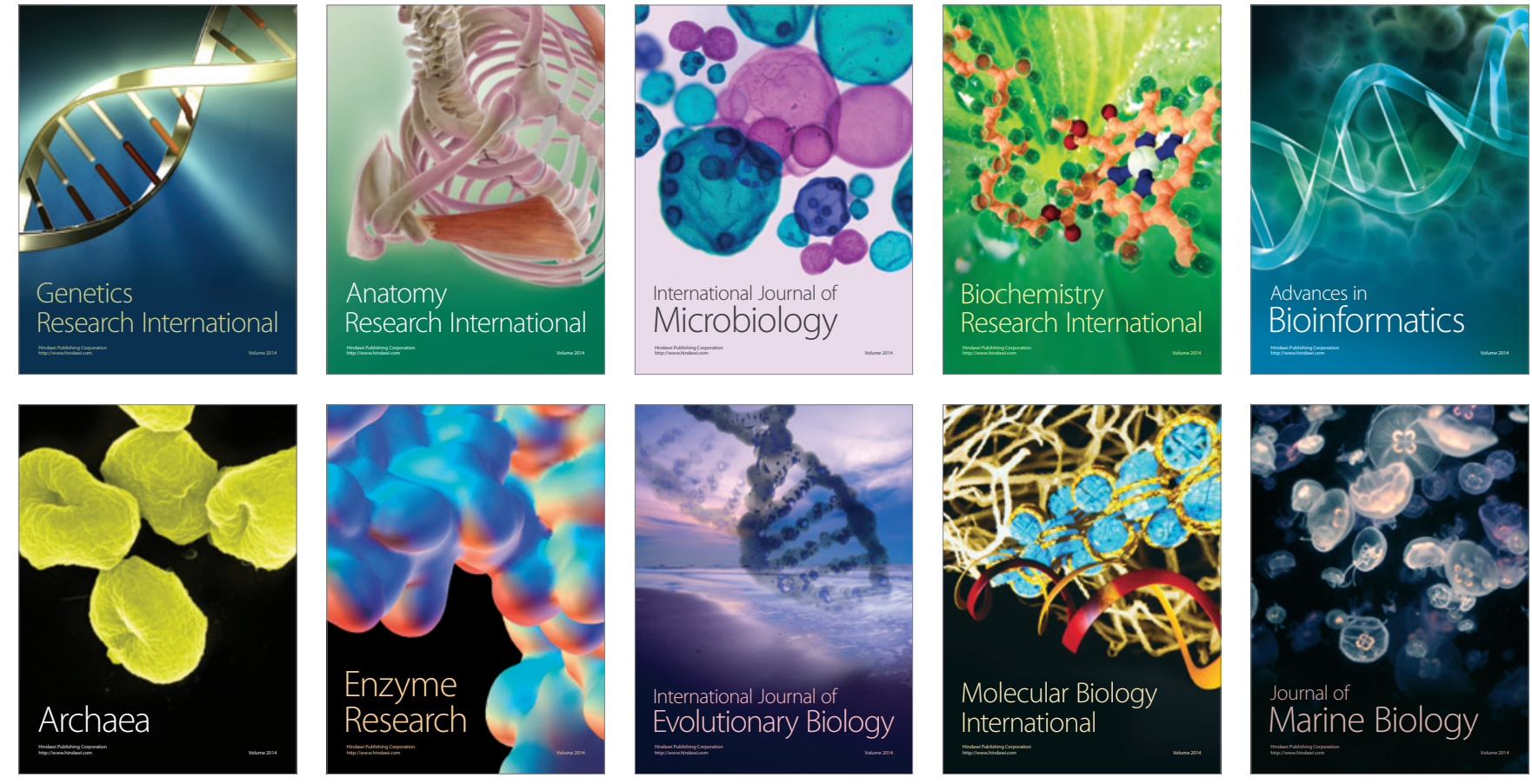